\title{
Oviductal secretion and gamete interaction
}

\author{
Sergio Ghersevich, Estefanía Massa and Carlos Zumoffen \\ Laboratory of Reproductive Studies, Area of Clinical Biochemistry, Facultad de Ciencias Bioquímicas y Farmacéuticas, \\ Universidad Nacional de Rosario, Suipacha 531, 2000 Rosario, Argentina
}

Correspondence should be addressed to S Ghersevich; Email: sghersev@fbioyf.unr.edu.ar

\begin{abstract}
Experimental evidence from the last 30 years supports the fact that the oviduct is involved in the modulation of the reproductive process in eutherian mammals. Oviductal secretion contains molecules that contribute to regulation of gamete function, gamete interaction, and the early stages of embryo development. The oviductal environment would act as a sperm reservoir, maintaining sperm viability, and modulating the subpopulation of spermatozoa that initiates the capacitation process. It could also contribute to prevent the premature acrosome reaction and to reduce polyspermy. Many studies have reported the beneficial effects of the oviductal environment on fertilization and on the first stages of embryo development. Some oviductal factors have been identified in different mammalian species. The effects of oviductal secretion on the reproductive process could be thought to result from the dynamic combined action (inhibitory or stimulatory) of multiple factors present in the oviductal lumen at different stages of the ovulatory cycle and in the presence of gametes or embryos. It could be hypothesized that the absence of a given molecule would not affect fertility as its action could be compensated by another factor with similar functions. However, any alteration in this balance could affect certain events of the reproductive process and could perhaps impair fertility. Thus, the complexity of the reproductive process warrants a continuous research effort to unveil the mechanisms and factors behind its regulation in the oviductal microenvironment.

Reproduction (2015) 149 R1-R14
\end{abstract}

\section{The oviduct}

The oviduct of eutherian mammals is the organ where the fertilization process takes place. It is a seromuscular tubular organ, whose distal part surrounds the ovary and whose proximal portion is attached to the uterus. Based on morphological and anatomical differences, the oviduct can be divided into four segments (composed of similar cell types, but in different proportions): the infundibulum (with the fimbriae surrounding the ovary), the ampulla, the isthmus, and the uterotubal junction (Fig. 1; Hess et al. 2006, Suarez 2006).

The ampulla is the site of oocyte fertilization. The mucosa of the ampulla shows a very complex pattern of folds, which are projected toward the oviductal lumen (Hess et al. 2006, Suarez 2006). The isthmic mucosa contains fewer folds than the ampulla.

The oviductal epithelium is mainly formed by columnar ciliated cells and secretory cells (showing surface microvilli); lymphoid cells can be observed close to the basement membrane. The secretory nonciliated columnar cells present a typical structure of cells that actively synthesize proteins (Suarez 2006). Marked differences in the morphological characteristics of the secretory granules from oviductal cells were reported in different species analyzed. In cattle, during the follicular phase of the estrous cycle, nonciliated cells of the ampulla and fimbriae contain large amount of secretory granules, while in the isthmus the number of cytoplasm granules was smaller and show different structural characteristics (Killian 2011).

Primate oviductal epithelial cells possess estrogen and progesterone receptors and undergo cyclical changes related to the menstrual cycle (Brenner et al. 1990, Hess et al. 2006). In the presence of progesterone, after estradiol levels decrease, loss of ciliated epithelium occurs and the secretory cells tend to lose their biosynthetic structures. Estrogens stimulate the secretion of the oviductal epithelium and this secretion is highest in the proliferative phase (Lippes et al. 1981, Suarez 2006, Killian 2011). The oviductal fluid contains amino acids, proteins, simple, and complex carbohydrates, ions, lipids, and phospholipids. Some of these components are metabolic substrates, such as lactate, pyruvic acid, amino acids, and glucose, whose levels differ from those present in the uterine fluid and the serum (Leese 1988, Leese et al. 2008, Hugentobler et al. 2010). Experimental evidence indicated that ion concentrations in oviductal fluid also differ from those of serum, suggesting that the oviductal epithelium modulates ion levels (Leese 1988, Leese et al. 2008, Hugentobler et al. 2010). 


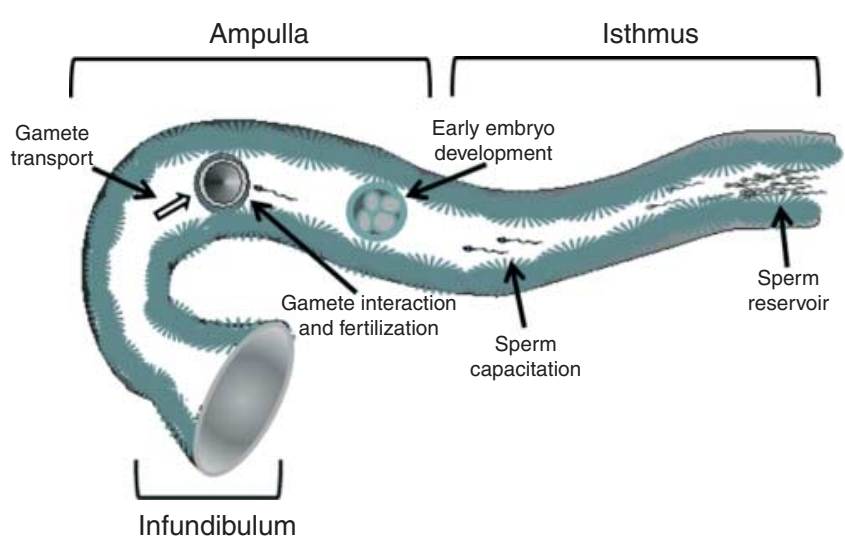

Figure 1 Schematic representation of the oviduct and its suggested involvement in the reproductive process.

The volume and some protein components of the oviductal fluid change throughout the cycle. Part of the complex mixture of proteins that are present in the oviductal fluid come from serum transudate, but there are also specific proteins synthesized and secreted by the oviductal epithelium, and some of them could be regulated by cyclic hormonal changes, with increased biosynthesis at the periovulatory period (Buhi et al. 2000, Buhi 2002).

Gamete transport within the oviductal lumen would be a highly controlled process (Suarez 2006, Kölle et al. 2009). There is evidence showing that the ciliary activity of the oviductal epithelial cells plays a key role in gamete and embryo transportation. It has been determined that the frequency of ciliary movement of the human oviductal epithelium increases after ovulation (Suarez 2006, Kölle et al. 2009).

The following pages will present a review of experimental data that support the central role of the oviduct and its secretion in the reproductive process (Fig. 2).

\section{Sperm-oviduct epithelial cell interaction}

Once spermatozoa reach the oviduct, they could follow two pathways. Some of them quickly migrate to the ampulla region, and usually they are not able to fertilize the oocyte, while most of spermatozoa are retained in the isthmus region forming a sperm reservoir, in the presence of the oviductal fluid (Figs 1 and 2; Croxatto 2002, Suarez 2008a). Some spermatozoa from the reservoir will retain their viability and their fertilizing ability until ovulation takes place (Suarez 2008a).

In different mammalian species, it has been shown that spermatozoa sequestered in the isthmus region could attach to epithelial cells, delaying sperm capacitation until ovulation-associated signals induce their release, allowing their transit to the ampulla. Such interaction would involve the sperm acrosomal region and the apical region of the oviduct epithelial cells, mainly of the ciliated cells (Petrunkina et al. 2001,
Croxatto 2002, Suarez 2008a, Coy et al. 2012a). In some mammals, such as canine, cattle, and horses, the interaction between spermatozoa and oviduct epithelial cells appears to be associated with sperm survival and capacitation state (Kawakami et al. 2001, Suarez 2006, 2008b). The molecular and biological mechanisms behind the sperm-epithelium interaction have not been clarified yet.

Different studies have investigated the effects of oviductal molecules that could be involved in the sperm-oviduct interaction. Members of the annexin family of proteins detected in the oviductal epithelium were identified as potential receptors for sperm proteins in bovine and porcine species (lgnotz et al. 2007, Suarez et al. 2008a, Teijeiro et al. 2009). Results from a recent study on pigs suggested that sperm binding to oviduct requires the presence of proteins with 6-sialylated biantennary glycans in the membrane of epithelial cells (Kadirvel et al. 2012).

\section{Participation of molecules from oviductal secretion in sperm-oviduct interaction}

Heparin and other sulfated glycoconjugates, which could be detected in oviductal fluid, were shown to induce the synchronous release of sperm adhering to bovine oviduct epithelium in vitro. Heparin-released sperm showed significantly higher intracellular $\mathrm{Ca}^{++}$ levels and increased levels of tyrosine-phosphorylated proteins compared with adhering spermatozoa (Gualtieri et al. 2005). Another study reported that uncapacitated bovine spermatozoa adhered to the oviduct, and their release was associated with capacitation (Talevi et al. 2007). The authors suggested that thiol-reducing agents in the oviductal fluid, such as sulfated glycoconjugates and disulfide reductants, may modulate the redox status of sperm surface proteins, leading to the release of

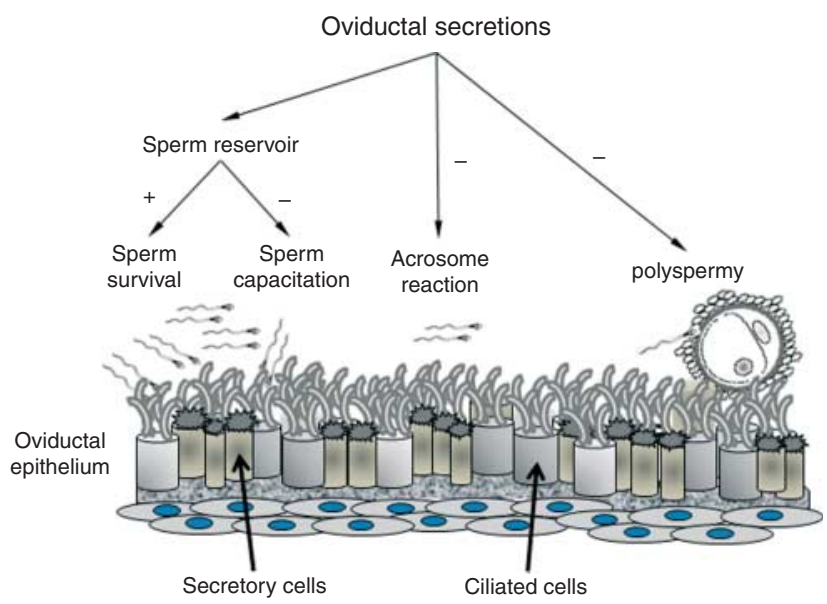

Figure 2 Reported effects of the oviductal secretions on gamete function and gamete interaction in different experimental models. The symbols ' + ' and ' - ' indicate stimulatory or inhibitory effects respectively. 
spermatozoa from the oviductal epithelium through the reduction of sperm surface protein disulfides to sulfhydryls (Talevi et al. 2007, Gualtieri et al. 2010).

An endocannabinoid known as anandamide is synthesized in the oviductal epithelia and detected in the oviductal fluid, and binds to cannabinoid receptors. These receptors were detected in mammalian reproductive tissues and male gametes from different species, such as human, porcine, and bovine species (Schuel et al. 2002a,b, Maccarrone et al. 2005, Rossato et al. 2005, Gervasi et al. 2009, Osycka-Salut et al. 2012). Gervasi et al. (2013) reported that anandamide levels in bovine oviductal fluid varied during estrous cycle, with the highest values detected during the periovulatory period, suggesting that this endocannabinoid levels may be regulated by ovarian hormones. It was reported that anandamide could modulate the bovine spermoviductal epithelium interaction, by inhibiting sperm binding and inducing sperm release from epithelial cells (Gervasi et al. 2009, Osycka-Salut et al. 2012). However, other authors observed that anandamide had no effects on sperm-oviduct binding and sperm release, but might contribute to the oviduct sperm-reservoir function, decreasing motility and capacitation, and prolonging sperm fertile life (Talevi et al. 2010).

\section{Oviductal secretion and sperm function}

Different experimental approaches have been used in order to assess the effects of the oviductal fluid on gamete function, fertilization, and the initial embryo development.

In some studies, the oviductal fluid was collected by placing a cannula in the oviduct (Leese 1988, Kavanaugh et al. 1992, Grippo et al. 1995, Way et al. 1997, Kumaresan et al. 2012).

In addition, the conditioned media from cultures of oviductal cells or tissue explants from different species were used to study the effects of the oviductal secretion on gamete function (Verhage et al. 1988, Yeung et al. 1994, Yao et al. 2000, Quintero et al. 2005, Munuce et al. 2009, Zumoffen et al. 2010).

Numerous studies in mammals have shown that the oviductal secretion or some of its components were able to modulate sperm function, sperm-zona interaction, and the process of fertilization (Fig. 2; RodriguezMartinez 2007, Mugnier et al. 2009, Killian 2011).

Co-incubation of spermatozoa with oviduct epithelial cells or their conditioned media maintained sperm viability and motility (Zhu et al. 1994, Kervancioglu et al. 2000, Quintero et al. 2005, Munuce et al. 2009, Zumoffen et al. 2010). However, the mechanisms by which oviductal cells and their secretory products favor the survival of spermatozoa remain unknown.

It has been reported that spermatozoa incubated in the presence of oviductal fluid or co-cultured with oviduct epithelial cells showed a pattern of hyperactivated motility related to the capacitation state, and it would be a preliminary step to undergo the acrosome reaction (Suarez, 2006, 2008b). It has also been observed that co-culture of sperm with oviductal cells or incubation in the presence of oviductal fluid showed beneficial effects on the human sperm membrane stabilization (Zhu et al. 1994, Yao et al. 1999). The decrease in human sperm response to acrosome reaction inducers in the presence of the oviductal cells or their conditioned media suggests that oviductal secretion could exert a stabilizing effect on sperm, contributing to avoid a premature acrosome reaction in the absence of the female gamete (Morales et al. 1996, Yao et al. 1999). Results from our laboratory indicated a significant decrease in the ionophoreinduced acrosome reaction in human sperm incubated previously in the presence of a conditioned medium from human oviductal tissue cultures (Quintero et al. 2005). Another study showed that the exposure of boar sperm to porcine oviductal fluid collected in the follicular phase of the estrous cycle promoted boar sperm viability and acrosomal integrity (Coy et al. 2010). A recent study has reported that incubation of boar sperm in the presence of pre-ovulatory oviductal fluid caused a significant increase in sperm protein tyrosine phosphorylation compared with incubation with postovulatory oviductal fluid or the control medium (Kumaresan et al. 2012). In addition, the observed phosphorylation patterns appeared to be individual dependent in porcine species.

Numerous research studies have investigated the oviductal factors that could be involved in the reported effects. The presence of adequate levels of bicarbonateand calcium seems to be essential in regulating sperm capacitation, motility, and acrosome reaction (Rodriguez-Martinez 2007, Leese et al. 2008, Abouhaila \& Tulsiani 2009, Lishko et al. 2012). Hyaluronan and sulfated glycosaminoglycans, such as heparin, have been detected in oviductal fluid from different mammalian species (Kawakami et al. 2000, Tienthai et al. 2000, 2004, Bergqvist \& Rodríguez-Martínez 2006). Glycosaminoglycans were involved in modulating sperm viability and capacitation in some species (Kawakami et al. 2000, Tienthai et al. 2000, Bergqvist \& Rodríguez-Martínez 2006).

Transuded serum proteins, such as albumin and HDLs, are found in the oviductal fluid and would be involved in the cholesterol efflux from sperm membrane during capacitation (Travis \& Kopf 2002, Leese et al. 2008, Abou-haila \& Tulsiani 2009).

\section{Involvement of oviductal proteins in sperm function}

The oviduct synthesizes and secretes proteins whose functions have not been clarified with certainty (Leese et al. 2008, Killian 2011). Notorious differences in the proteomic profiles of the oviduct between follicular and luteal phases of the reproductive cycle in pig were 
reported (Seytanoglu et al. 2008). In addition, the presence of gametes appears to alter the pattern of protein synthesis and secretion of the oviductal cells. Supporting this idea, the binding of equine spermatozoa to homologous oviductal cells could change the pattern of protein secretion of the epithelial cells (Thomas et al. 1995a). The authors suggested that, during this interaction, spermatozoa would be exposed to oviductal protein factors that would maintain their viability and motility and would also facilitate the elimination of deleterious metabolic products (Thomas et al. 1995b). Georgiou et al. $(2005,2007)$ also showed that the presence of spermatozoa in the pig oviduct could alter the expression and secretion of specific oviductal proteins.

Recently, we have shown that proteins from conditioned media of oviduct tissue culture decreased the follicular fluid-induced acrosome reaction and the phosphorylation in tyrosine residues of human sperm proteins in a dose-dependent manner (Zumoffen et al. 2010).

In the last 30 years, several investigations have been directed to identify proteins from the oviductal fluid to analyze their potential effects on the reproductive process. Some of these oviductal proteins and their reported actions will be described as follows.

\section{Oviductins}

The production and secretion of high-molecular-weight (MW 70-130 kDa) glycoproteins from the oviductal epithelium seem to be associated with hormonal changes during the ovulatory cycle in different species (Buhi et al. 2000, Buhi 2002, Leese et al. 2008, Avilés et al. 2010). Oviductins, also known as oviduct-specific glycoproteins, have been found in the oviducts of every mammalian species studied to date, and the cDNA sequences for these glycoproteins indicated that they show a high homology among species (Donnelly et al. 1991, Arias et al. 1994, Sendai et al. 1995, Buhi et al. 1996). Bovine oviductin, referred to as an estrusassociated protein, was isolated from the oviductal fluid and was able to bind to the head and middle piece of spermatozoa (King \& Killian 1994). Bovine oviductin has been shown to promote in vitro sperm capacitation and maintain both the viability and motility of spermatozoa compared with the control medium without any added protein and these effects were dose dependent (King et al. 1994, Abe et al. 1995). Mouse oviductin has been shown to bind to the equatorial and acrosomal regions of mouse sperm heads (Lyng \& Shur 2009). Other studies indicated that hamster oviductin bound to the anterior acrosomal region of the sperm and enhanced sperm capacitation (Kimura et al. 1994, Saccary et al. 2013). In addition, it was reported that the sperm-binding sites of hamster oviductin were related to the sperm capacitation status and the acrosome reaction (Kan \& Esperanzate 2006).

\section{Osteopontin}

This phosphoprotein, which contains repetitive amino acid sequences of arginine-glycine-aspartic acid (RGD), was detected in the bovine oviductal secretion and shown to have a variable expression throughout the estrous cycle (Gabler et al. 2003). Glycoproteins containing the RGD recognition sequence, which would be ligands of integrins, could be present on the extracellular cover of bovine oocytes and sperm (Ikawa et al. 2010). A study by Souza et al. (2008) revealed that distribution of sperm-binding sites of osteopontin changed after incubation in the bovine oviductal fluid, and the authors suggested that the protein could participate in sperm-oocyte interaction. Another study has reported that osteopontin increased bovine sperm capacitation (Monaco et al. 2009).

\section{Glycodelins}

These glycoproteins have been detected in the human oviduct at least in four isoforms, namely glycodelin $\mathrm{S}$, glycodelin A, glycodelin F, and glycodelin C, based on the differences in glycosylation (Yeung et al. 2006, Chiu et al. 2007a, b). Glycodelins are highly homologous to beta-lactoglobulins, which were detected in the female reproductive tract from several species (Huhtala et al. 1987). Glycodelin A is produced and secreted by the oviductal epithelium. Recombinant glycodelin A was shown to inhibit capacitation of human and hamster spermatozoa (Dutta et al. 2001). Glycodelin F is expressed in the human oviductal epithelium and in granulosa luteal cells and was shown to bind to the acrosomal region of human sperm head and suppress the progesterone-induced AR (Yeung et al. 2006). Thus, it was suggested that glycodelin $\mathrm{F}$ could help to prevent a premature acrosome reaction, before the human spermatozoa contact the zona pellucida (ZP; Yeung et al. 2007). Glycodelin C, generated from glycodelins A and $\mathrm{F}$ in oocyte cumulus cells, has been shown to bind to sperm head, mainly in the equatorial region (Chiu et al. 2007b).

\section{Atrial natriuretic peptide}

This peptide is expressed in the pig oviductal epithelium and is present in the oviductal fluid. Its receptor was detected in spermatozoa (Zhang et al. 2006). The preincubation of boar spermatozoa with atrial natriuretic peptide has been shown to induce the acrosome reaction (Zhang et al. 2006).

\section{Sperm adhesion molecule 1 (SPAM1)}

This protein is a hyaluronidase also known as $\mathrm{PH}-20$ present in sperm membrane. It has been found to be secreted in the female reproductive tract (including the oviduct) and it can bind to sperm (Griffiths et al. 2008). It was shown that hyaluronic acid interacts with the 
$\mathrm{PH}-20$ protein anchored on the macaque and human sperm membrane increasing the basal levels of intracellular calcium and promoting the induced acrosome reaction (Sabeur et al. 1998, Cherr et al. 1999).

\section{Lactoferrin}

This glycoprotein was isolated in our laboratory from the conditioned medium of human oviductal tissue culture based on its binding ability to sperm membrane and was further identified as human lactoferrin (Zumoffen et al. 2013). It was detected in tubal fluid and appeared to be estrogen regulated in human oviduct epithelial cells (Zumoffen et al. 2013). Results of our study indicated that lactoferrin presents different binding patterns to sperm related to the capacitation status and the acrosome reaction, suggesting that the protein could participate in sperm-oocyte interaction (Fig. 3; Zumoffen et al. 2013). In addition, lactoferrin was able to modulate some sperm functions related to capacitation (C Zumoffen and S Ghersevich unpublished observations).
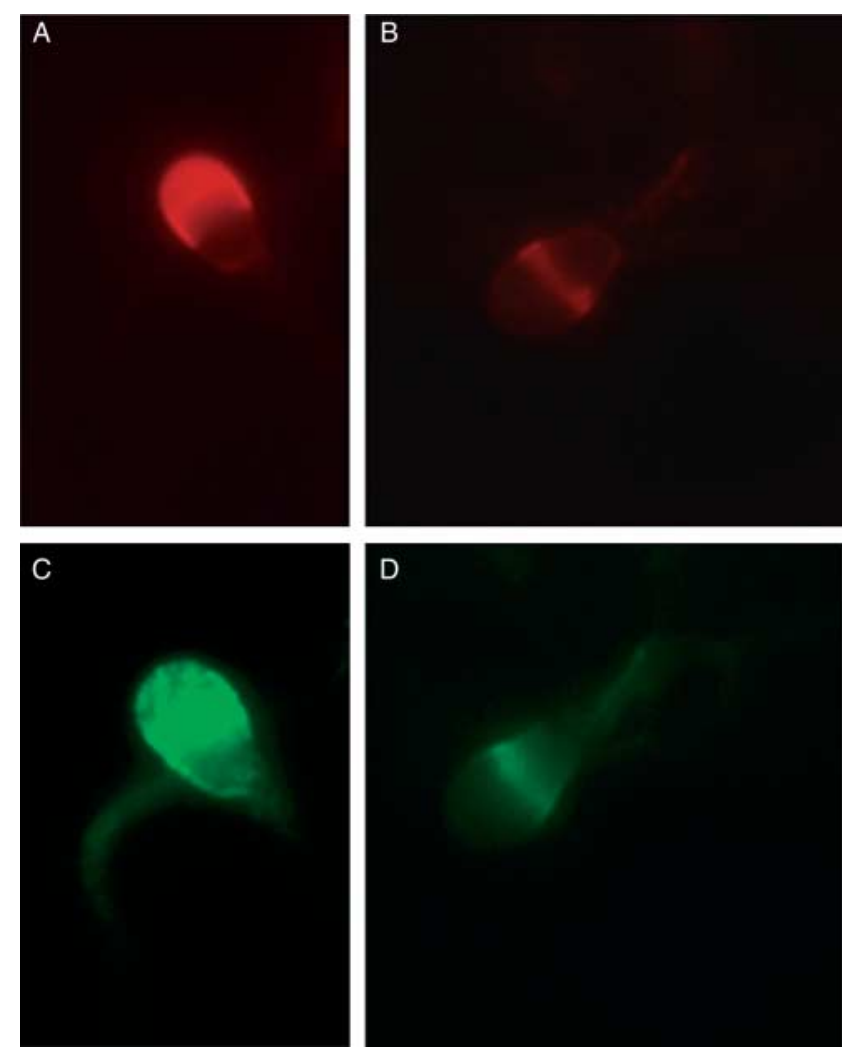

Figure 3 Fluorescence micrographs showing the acrosomal staining (detected with Pisum sativum-rhodamine) and the binding of FITCconjugated lactoferrin in human spermatozoa incubated under capacitating conditions. (A) Intact acrosome sperm. (B) Acrosomereacted sperm. (C) Lactoferrin localized to the sperm head in the same cell as (A). (D) Lactoferrin was detected mainly in the equatorial segment in the same spermatozoon as (B).

\section{Involvement of oviductal secretion in gamete interaction}

Numerous studies have investigated the effects of the oviductal secretion on gamete interaction. Experiments conducted on cows have shown that the presence of nonluteal oviductal fluid or fluid collected from the isthmic oviductal region increased more sperm-zona binding than the fluid collected in the luteal stage of the estrous cycle or the fluid from the ampulla respectively (Grippo et al. 1995, Way et al. 1997). The authors suggested that the effects of bovine oviductal fluid on gamete function and interaction depended on the oviductal region and the stage of the estrous cycle (Grippo et al. 1995, Way et al. 1997). Taitzoglou et al. (2007) reported changes in exposed saccharide residues of bovine sperm during capacitation in the presence of oviductal fluid and they suggested that these modifications could influence sperm-zona binding, zona penetration, and interaction with the oolemma.

It has been reported that the exposure of hamster oocytes to the oviductal environment increased sperm-zona binding, zona penetration and fertilization (Boatman et al. 1994). In accordance with the previous results, incubation of hamster oocytes in the presence of oviductal fluid improved both sperm-zona binding, zona penetration and fertilization (Kito \& Bavister 1996).

A study conducted on dogs reported that incubation in the presence of oviductal fluid increased the sperm-ZP binding (Kawakami et al. 1998). Another study revealed that co-culture of equine gametes with homologous and heterologous (porcine) oviductal cells increased equine IVF rates (Mugnier et al. 2009). Coy et al. (2010) reported that exposure of boar spermatozoa to preovulatory porcine oviductal fluid increased zona binding and polyspermy during IVF.

In the case of human species, co-incubation with oviductal cells or their conditioned media was found to reduce the human sperm binding to ZP (Morales et al. 1996, Yao et al. 1999).

It has been shown that exposure of ZP to oviductal fluid increased ZP resistance to proteolysis. This effect was associated with reduced polyspermy by decreasing sperm-ZP binding in porcine and bovine species (Coy et al. 2008). The increased ZP resistance to proteolysis by oviductal fluid seems not to be species specific, at least among ruminants and rabbits (Katska et al. 1989, 1999). Supporting this suggestion partially, the presence of human oviductal fluid increased $\mathrm{ZP}$ resistance to proteolysis in rabbit, sheep, pig, and bovine species, but not in human species, suggesting that this effect could depend on the species (Mondéjar et al. 2013a).

\section{Involvement of oviductal proteins in gamete interaction}

Experimental evidence supports that proteins play a central role in modulating gamete interaction. Once the 
spermatozoon detects the oocyte, it must cross two barriers, the cumulus cells and the $\mathrm{ZP}$, before it could contact the female gamete plasma membrane (Ikawa et al. 2010, Coy et al. 2012a; Fig. 2). The ZP is a glycoprotein cover that surrounds the oocyte in mammals and would be responsible for the species specificity of gamete interaction (Wassarman et al. 1999).

It has been suggested that species-specific zona adhesion is not mediated by a single receptor. Instead, sperm-zona binding would involve a multiplicity of receptor-ligand interactions and would require the coordinated action of different proteins (Nixon et al. 2005, Gahlay et al. 2010, Clark et al. 2011, Avella et al. 2013). The initial mouse sperm-zona binding could also involve components of the ZP acquired in the oviduct after ovulation (Lyng \& Shur 2009).

Experimental evidence suggested that there is a dynamic aggregation of zona proteins believed to be important in sperm-ZP recognition to the regions of sperm that mediate this binding event (Gahlay et al. 2010). In addition, a recent study has demonstrated that mannose, fucose, and $\beta-N$-acetylglucosamine were terminal carbohydrates on the mouse oocyte ZP involved in cross-linking or aggregation with receptors on the sperm membrane (Wu \& Sampson 2014). It has been suggested that mouse sperm receptors for zona proteins interact with both the glycans and the protein backbone of the ZP (Clark et al. 2011).

It has been proposed that the interaction between integrin-like proteins on the oolemma and disintegrins of transmembrane proteins that contains a disintegrin and metalloprotease domain (ADAM), found on the sperm membrane would be involved in the gamete fusion process (Ikawa et al. 2010, Inoue et al. 2011). However, this idea is mainly supported by results obtained from studies on the fusion of gamete membranes carried out in mouse models.

Different experimental approaches have demonstrated that oviductal proteins could interact with gametes and affect gamete interaction (Fig. 2). A previous study has reported that six proteins from the bovine oviductal fluid were attached to the homologous ZP (Staros \& Killian 1998). In a study carried out in our laboratory, the presence of proteins from the conditioned media of human oviductal tissue culture resulted in a dose-dependent inhibition of the sperm-ZP binding and decreased the detection of sperm D-mannose-binding sites, which are associated with gamete interaction (Munuce et al. 2009).

Some of the oviductal proteins suggested to be involved in modulating gamete interaction have been identified and their reported effects are described below.

\section{Oviductins}

These glycoproteins secreted by the oviductal epithelium were shown to interact with the oocyte ZP in different species. O'Day-Bowman et al. (1996) reported that incubation of human or baboon spermatozoa in the presence of the oviductin increased hemizona binding and penetration to hamster oocytes. The presence of oviductin also increased the in vitro sperm fertilizing ability in bovine species (King et al. 1994, Martus et al. 1998). Oviductins were suggested to participate in the initial sperm-zona adhesion in mice and were found to be associated with both the ZP and the perivitelline space of mouse oocytes (Ensslin et al. 2007, Lyng \& Shur 2009). Despite the results mentioned above, a study using Ovgp $1^{-/}$mice indicated that fertility of $O v g p 1^{-1-}$ females was within the normal limits, suggesting that, at least in mice, the protein was not essential for the process of in vivo fertilization (Araki et al. 2003).

An early study demonstrated that hamster oviductin was bound to the ZP during transit of the oocyte in the oviduct (St-Jacques et al. 1992). However, the exposure to oviductin was shown to decrease the sperm-zona interaction and inhibit IVF of cumulus-free oocytes in hamsters (Kimura et al. 1994, Saccary et al. 2013). It has been reported that exposure to porcine oviductin before and during IVF decreased the incidence of polyspermy in pig oocytes and reduced the number of bound sperm (Kouba et al. 2000, McCauley et al. 2003). Oviductin and heparin-like glycosaminoglycans have been implicated in the pre-fertilization ZP hardening in cows and pigs, which could affect sperm binding and would contribute to prevent polyspermy (Coy et al. 2008). In addition to oviductin, proteins from the heat shock protein family and the protein disulfide isomerase A4 appear to be involved in ZP hardening in bovine species (Mondéjar et al. 2013b).

\section{Osteopontin}

A study on bovine species demonstrated the binding of osteopontin (which is secreted by the oviductal epithelium) to the ZP (Gonçalves et al. 2008). It has also been reported that the pre-incubation of spermatozoa or oocytes with oviductal fluid pre-treated with antibodies against osteopontin reduced sperm-ZP binding and IVF (Gonçalves et al. 2007, 2008). Another study has demonstrated that the exposure to osteopontin during IVF decreased polyspermy in pigs (Hao et al. 2006, 2008). In addition, it has also been demonstrated that exposure to osteopontin during IVF also increased the fertilization efficiency in pigs and slightly increased the IVF rates in equine species (Hao et al. 2006, 2008, Mugnier et al. 2009).

\section{Glycodelins}

Exposure to glycodelin A has been shown to decrease human gamete interaction in vitro (Oehninger et al. 1995). This effect would result from blocking the binding of the sperm fucosyltransferase 5 (suggested to be the sperm glycodelin A receptor) to the ZP (Chiu et al. 2007a). The presence of glycodelin $F$ has also been reported to reduce gamete interaction (Chiu et al. 2003). 
Glycodelin C would remove the previously attached glycodelins $\mathrm{A}$ and $\mathrm{F}$ from spermatozoa, enhancing the zona-binding capacity of sperm passing through the cumulus oophorus (Chiu et al. 2007b).

\section{HSPA5}

This protein also known as GRP8 was first isolated from the plasma membrane of oviduct epithelial cells and its expression in these cells changed throughout the estrous cycle and would be under hormonal control (Bauersachs et al. 2004, Boilard et al. 2004). The presence of this protein was detected in human oviductal fluid and the conditioned medium from tubal tissue cultures (MarínBriggiler et al. 2010). Recombinant GRP78 was found to bind to spermatozoa and was able to decrease sperm-zona interaction in a dose-dependent manner (Marín-Briggiler et al. 2010).

\section{Atrial natriuretic peptide}

It has been shown that pre-incubation of spermatozoa with this peptide increased the oocyte penetration rate and decreased the polyspermy rate and the average number of sperm per penetrated oocyte in pigs (Zhang et al. 2006).

\section{S100A11}

The expression of this protein, which belongs to the $\mathrm{S} 100$ family of proteins, was detected in the oviductal epithelium, mainly in the ampullary region of the mouse oviduct and at the estrous stage of the estrous cycle (Hanaue et al. 2011). S100A11 was also detected bound to the plasma membrane of cumulus cells surrounding the oocytes. Pre-treatment of the cumulus cell-oocyte complex with recombinant S100A11 significantly reduced the efficiency of IVF in mice. The authors suggested that the effect could be mediated through the binding of S100A11 to the plasma membrane of the cumulus cells (Miwa et al. 2010, Hanaue et al. 2011).

\section{Deleted in malignant brain tumors 1 (DMBT1)}

This protein was shown to be expressed by the oviductal epithelium and was localized to the ZP and the cytoplasm of oocytes in equine and porcine species (Ambruosi et al. 2013). Pre-incubation of oocytes with recombinant deleted in malignant brain tumors 1 (DMBT1) increased the monospermic IVF rate in pigs (Ambruosi et al. 2013). The reported effect was also observed when oviductal fluids were used instead of the recombinant protein, but there was no effect when an antibody against DMBT1 was previously added to the oviductal fluid (Ambruosi et al. 2013).

\section{Glycosidase enzymes}

These enzymes have been detected in hamster, porcine, and bovine oviductal secretion (Tulsiani et al. 1996,
Carrasco et al. 2008a, b). It has been suggested that these enzymes could affect the protein and carbohydrate distribution on the sperm and the ZP surface and could modulate sperm-oocyte binding and gamete-oviductal epithelium interaction, both suggested to be carbohydratemediated events occurring in the presence of the oviductal fluid (Carrasco et al. 2008a, b).

\section{Proteases}

Plasminogen activators were detected in porcine and bovine oviductal flushing and their relative concentrations were found to change during the ovulatory cycle (Roldán-Olarte et al. 2005). Plasminogen is present in the oviductal fluid through the estrous cycle (Mondéjar et al. 2012). Plasminogen activators and their main substrate, plasminogen, were also found in the cumulus cell extracellular matrix and oocyte ZP (Roldán-Olarte et al. 2005, Mondéjar et al. 2012). A recent study has demonstrated that the presence of plasminogen in the IVF medium decreased sperm penetration of oocytes in porcine and bovine species (Mondéjar et al. 2012). It has been suggested that sperm binding to oocytes triggers the releasing of plasminogen activators from the oocyte and the generated plasmin causes sperm detachment from the ZP (Coy et al. 2012b). Supporting this idea, it has been reported that, after fertilization, plasminogen and plasminogen activator immunolabeling decreases in the oocyte, suggesting its conversion into plasmin (Mondéjar et al. 2012).

\section{Sperm adhesion molecule 1}

This hyaluronidase, together with other enzymes, has been implicated in assisting the sperm penetration through the cumulus cell layer surrounding the ZP (Lin et al. 1994). It has also been involved in the binding of acrosome-reacted sperm to the ZP (Myles \& Primakoff 1997, Redgrove et al. 2013).

\section{Lactoferrin}

In a recent study, human lactoferrin was shown to bind to ZP. In addition, the presence of the protein caused a dosedependent decrease in the human sperm-zona interaction (Zumoffen et al. 2013). Lactoferrin was also shown to reduce the availability of sperm D-mannose receptors (C Zumoffen and S Ghersevich, unpublished observations). The latter effect could partially explain the inhibition of sperm-zona binding in the presence of the protein.

\section{Involvement of oviductal secretion in embryo development}

Some studies have suggested that co-culture of gametes or embryos with oviduct epithelial cells benefits IVF rate and embryo development respectively (Liu et al. 1995, Wiemer et al. 1995, Romar et al. 2001, Kattal et al. 2008, 
Mugnier et al. 2009). However, these results were not supported by studies on other mammalian species (Izquierdo et al. 2002, Kidson et al. 2003, Shirazi \& Motaghi 2013). The difference in the mentioned results may reflect the fact that every study was performed under very different conditions. However, potential speciesspecific effects of co-culture with oviductal cells on embryo development could not be ruled out, but they remain to be demonstrated yet.

It has been proposed that co-culture with oviduct epithelial cells would reduce the undesirable factors in the culture medium and this would benefit embryo development. It is possible that epithelial cells, through their metabolic capacity, reduce the atmospheric oxygen pressure and the levels of substances such as glucose, which act as inhibitors of embryonic development in vitro. Another possible mechanism would involve the production of embryotropic factors, such as certain growth factors, whose presence in the oviduct has been clearly documented. Growth factors in the oviduct were suggested to be involved in preimplantation embryo development (Dalton et al. 1994, Einspanier et al. 1999, Pushpakumara et al. 2002, Wijayagunawardane et al. 2005, Itoh et al. 2006, Sun et al. 2006, Kawamura et al. 2007, Weng et al. 2009, Swangchan-Uthai et al. 2011).

It has been reported that the condition of the oviduct where bovine embryos were placed until reaching the blastocyst stage influenced their gene expression patterns, especially for those genes that regulate metabolic activity (Gad et al. 2011). Thus, factors from the oviductal secretion could affect the embryo gene expression.

In addition, Lee et al. $(2005,2006)$ have analyzed the interaction between embryos and oviduct in mice and their results suggested that the presence of the embryo could affect the protein expression of the mouse oviductal epithelium, as shown for the phospholipid transfer protein (PLTP) and the demilune cell and parotid protein.

\section{Phospholipid transfer protein}

In the presence of an embryo, the mouse oviductal epithelium secretes PLTP, which showed a higher expression in the embryo-containing oviduct than in the control oviduct (Lee et al. 2005). As Pltp mRNA increased in the oviductal epithelia of pregnant mice, the authors suggested that it could be involved in in vivo preimplantation embryo development (Lee et al. 2005).

\section{Demilune cell and parotid protein}

This protein was also highly expressed in mouse oviductal lumen in the presence of embryos (Lee et al. 2006). Demilune cell and parotid protein was shown to stimulate the growth of preimplantation embryos, suggesting that it may participate in embryo-maternal dialog (Lee et al. 2006). Other proteins present in the oviductal secretion suggested to be involved in modulating embryo development are mentioned below.

\section{Oviductins}

They were localized to the perivitelline space and the membrane of embryos from different species before the implantation. Their densely glycosylated mucin-type domains would act as a protective shield around the oocyte and the early embryo and would be important for early stages of embryo development (Malette et al. 1995, Boatman 1997, Velasquez et al. 2001, Buhi 2002, Wolf et al. 2003, Gonçalves et al. 2008). Porcine oviductin increased post-cleavage embryo development to blastocyst (Kouba et al. 2000, McCauley et al. 2003). In a study on goats, Pradeep et al. also reported that oviductin increased the cleavage rate, and morula and blastocyst formation (Pradeep et al. 2011).

\section{Osteopontin}

A study on bovine species reported that pre-incubation of oocytes with oviductal fluid pre-treated with antibodies against osteopontin reduced the in vitro embryo development when compared with the oviductal fluid alone (Gonçalves et al. 2008). Supporting the mentioned results, the presence of osteopontin improved the efficiency of in vitro embryo production in bovine species (Monaco et al. 2009). In addition, the exposure to osteopontin during IVF has also been shown to improve in vitro development of porcine embryos (Hao et al. 2006, 2008).

\section{Human oviduct-derived embryotropic factor 3}

This factor contains complement protein 3 (C3) and its derivatives $\mathrm{C} 3 \mathrm{~b}$ and inactivated complement $3 \mathrm{~b}$ (iC3b) (Lee at al. 2004). C3 is produced and secreted by human and mouse oviductal cells. Both derivatives, but not C3, were embryotropic, while iC3b was most efficient in enhancing the mouse blastocyst development, with larger size and higher hatching rate (Lee at al. 2004). Oviductal cells possess C3 convertase activity converting C3 to C3b (Tse et al. 2008). It has been shown that the mouse preimplantation embryos may cooperate with oviductal cells to produce embryotropic iC3b (Tse et al. 2008). The levels of $\mathrm{C} 3$ and $\mathrm{iC} 3 \mathrm{~b}$ in mouse oviductal fluid were highest on day 3 of pregnancy, when they could enhance the blastocyst development and result in larger size and higher embryo hatching rate in vitro (Lee et al. 2009). Based on these data, it has been suggested that the oviduct produced $\mathrm{C} 3 / \mathrm{C} 3 \mathrm{~b}$, which could be converted into $\mathrm{iC} 3 \mathrm{~b}$ in the presence of the embryo stimulating its development.

\section{Concluding remarks}

Until a few decades ago, the oviduct was considered as a simple passive conduit that provided an optimal microenvironment in terms of temperature, $\mathrm{pH}$, osmotic pressure, nutrients, and oxygen pressure, enabling both 
the fertilization process and the early stages of embryo development (Pauerstein \& Eddy 1979). The accumulated experimental evidence reviewed in the present work supports that the oviduct is actively involved in the reproductive process, considering that its secretion contains molecules capable of modulating gamete functions and interaction. It would also contribute to regulate the early stages of embryo development.

Based on the reported data in different mammalian species, it has been considered that spermatozoa in the oviduct interact with factors that would help select subpopulations of male gametes that remain viable while developing an optimal fertilizing ability. The oviductal environment would also contribute to decrease the number of sperm that could interact with the oocytes.

Numerous studies have identified specific molecules, most of which are proteins, in the oviductal environment that could be involved in modulating different stages of the reproductive process. The expression of certain protein components of the oviductal secretion would be subject to cyclic changes of sex steroids. In addition, the presence of gametes or embryos could affect the protein expression from oviductal epithelial cells. It could be thought that the resulting effect of the oviductal secretion, either inhibitory or stimulatory, on the reproductive process would result from the dynamic cooperative action of multiple factors present in the oviduct at different stages of the ovulatory cycle (Fig. 4). The combined action of these factors, either inducers

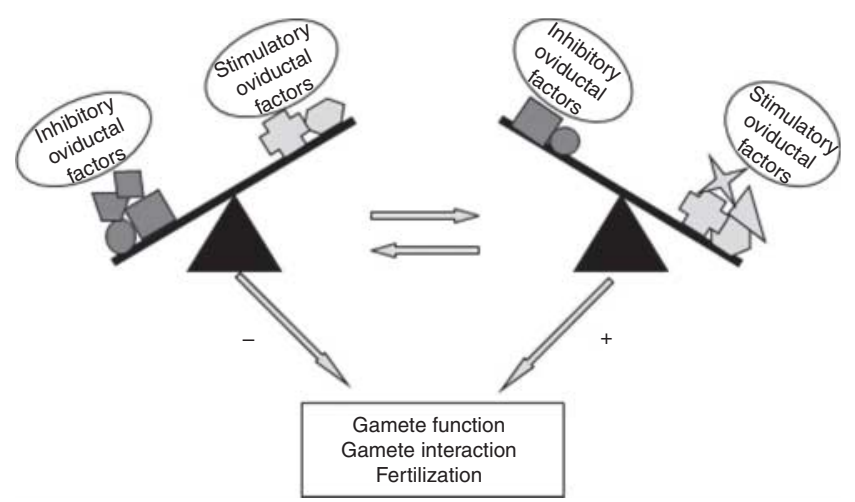

Figure 4 Drawing showing the suggested actions of the oviductal secretion in different stages of the reproductive process. The effect of the oviductal secretion would result from the combined action of several factors, either stimulatory or inhibitory. The balance between the stimulatory and inhibitory effects would result from the regulation of the expression of these oviductal factors, which could be dependent on the ovulatory cycle and the oviductal region, induced by the presence of gametes, constitutive, or even associated with a given disorder. Among oviductal proteins from different species with potential inhibitory actions, the following ones could be mentioned: glycodelins $A$ and $F$, GRP78, S100 A11, and lactoferrin. On the other hand, proteins such as oviductins, osteopontin, atrial natriuretic peptide, glycodelin C, and sperm adhesion molecule 1 were reported to have some stimulatory effects in vitro. The symbols ' + ' and ' $-{ }^{\prime}$ indicate stimulatory or inhibitory effects respectively. or repressors, could contribute to the regulation of the complex mechanism of reproduction in the oviduct. The balance between the stimulatory and inhibitory effects would result from the regulation of the expression of these oviductal factors, which could be dependent on the ovulatory cycle and the oviductal region, induced by the presence of gametes or embryos, constitutive, or even influenced by individual characteristics or by certain disorders. Thus, the deficiency of a given molecule might not impair fertility capacity because its action could be compensated by another factor with similar functions. However, any alteration in this balance could affect some stages of the reproductive process and could perhaps impair fertility.

Therefore, the complexity of the reproductive process warrants a continuous research effort to unveil the mechanisms and oviductal factors behind its regulation.

\section{Declaration of interest}

The authors declare that there is no conflict of interest that could be perceived as prejudicing the impartiality of the review.

\section{Funding}

This review did not receive any specific grant from any funding agency in the public, commercial, or not-for-profit sector.

\section{Acknowledgements}

The authors thank M Robson, M de Sanctis, and G Raimundo for their assistance in manuscript proofreading.

\section{References}

Abe H, Sendai Y, Satoh T \& Hoshi H 1995 Bovine oviduct-specific glycoprotein: a potent factor for maintenance of viability and motility of bovine spermatozoa in vitro. Molecular Reproduction and Development 42 226-232. (doi:10.1002/mrd.1080420212)

Abou-haila A \& Tulsiani DR 2009 Signal transduction pathways that regulate sperm capacitation and the acrosome reaction. Archives of Biochemistry and Biophysics 485 72-81. (doi:10.1016/j.abb.2009. 02.003)

Ambruosi B, Accogli G, Douet C, Canepa S, Pascal G, Monget P, Moros Nicolás C, Holmskov U, Mollenhauer J, Robbe-Masselot C et al. 2013 Deleted in malignant brain tumor 1 is secreted in the oviduct and involved in the mechanism of fertilization in equine and porcine species. Reproduction 146 119-133. (doi:10.1530/REP-13-0007)

Araki $Y$, Nohara M, Yoshida-Komiya H, Kuramochi T, Ito M, Hoshi H, Shinkai Y \& Sendai Y 2003 Effect of a null mutation of the oviductspecific glycoprotein gene on mouse fertilization. Biochemical Journal 374 551-557. (doi:10.1042/BJ20030466)

Arias EB, Verhage HG \& Jaffe RC 1994 Complementary deoxyribonucleic acid cloning and molecular characterization of an estrogen-dependent human oviductal glycoprotein. Biology of Reproduction 51 685-694. (doi:10.1095/biolreprod51.4.685)

Avella MA, Xiong B \& Dean J 2013 The molecular basis of gamete recognition in mice and humans. Molecular Human Reproduction 19 279-289. (doi:10.1093/molehr/gat004) 
Avilés M, Gutiérrez-Adán A \& Coy P 2010 Oviductal secretions: will they be key factors for the future ARTs? Molecular Human Reproduction 16 896-906. (doi:10.1093/molehr/gaq056)

Bauersachs S, Rehfeld S, Ulbrich SE, Mallok S, Prelle K, Wenigerkind H, Einspanier R, Blum H \& Wolf E 2004 Monitoring gene expression changes in bovine oviduct epithelial cells during the oestrous cycle. Journal of Molecular Endocrinology 32 449-466. (doi:10.1677/jme.0. 0320449)

Bergqvist AS \& Rodríguez-Martínez H 2006 Sulphated glycosaminoglycans (S-GAGs) and syndecans in the bovine oviduct. Animal Reproduction Science 93 46-60. (doi:10.1016/j.anireprosci.2005.06.029)

Boatman DE 1997 Responses of gametes to the oviductal environment. Human Reproduction 12 133-149.

Boatman DE, Felson SE \& Kimura J 1994 Changes in morphology, sperm penetration and fertilization of ovulated hamster eggs induced by oviductal exposure. Human Reproduction 9 519-526.

Boilard M, Reyes-Moreno C, Lachance C, Massicotte L, Bailey JL, Sirard MA \& Leclerc P 2004 Localization of the chaperone proteins GRP78 and HSP60 on the luminal surface of bovine oviduct epithelial cells and their association with spermatozoa. Biology of Reproduction 71 1879-1889. (doi:10.1095/biolreprod.103.026849)

Brenner RM, West NB \& McClellan MC 1990 Estrogen and progestin receptors in the reproductive tract of male and female primates. Biology of Reproduction 42 11-19. (doi:10.1095/biolreprod42.1.11)

Buhi WC 2002 Characterization and biological roles of oviduct-specific, oestrogen-dependent glycoprotein. Reproduction 123 355-362. (doi:10. 1530/rep.0.1230355)

Buhi WC, Alvarez IM, Choi I, Cleaver BD \& Simmen FA 1996 Molecular cloning and characterization of an estrogen-dependent porcine oviductal secretory glycoprotein. Biology of Reproduction 55 1305-1314. (doi:10. 1095/biolreprod55.6.1305)

Buhi WC, Alvarez IM \& Koube AJ 2000 Secreted proteins of the oviduct. Cells, Tissues, Organs 166 165-179. (doi:10.1159/000016731)

Carrasco LC, Romar R, Aviles M, Gadea J \& Coy P 2008a Glycosidase determination in bovine oviductal fluid at the follicular and luteal phases of the oestrous cycle. Reproduction, Fertility, and Development 20 808-817. (doi:10.1071/RD08113)

Carrasco LC, Romar R, Aviles M, Gadea J \& Coy P 2008b Determination of glycosidase activity in porcine oviductal fluid at different phases of the estrous cycle. Reproduction 136 833-842. (doi:10.1530/REP-08-0221)

Cherr GN, Yudin Al, Li MW, Vines CA \& Overstreet JW 1999 Hyaluronic acid and the cumulus extracellular matrix induce increases in intracellular calcium in macaque sperm via the plasma membrane protein PH-20. Zygote 7 211-222. (doi:10.1017/S0967199499000593)

Chiu PC, Koistinen R, Koistinen H, Seppala M, Lee KF \& Yeung WS 2003 Zona-binding inhibitory factor-1 from human follicular fluid is an isoform of glycodelin. Biology of Reproduction 69 365-372. (doi:10. 1095/biolreprod.102.012658)

Chiu PC, Chung MK, Koistinen R, Koistinen H, Seppala M, Ho PC, Ng EH, Lee KF \& Yeung WS 2007a Glycodelin-A interacts with fucosyltransferase on human sperm plasma membrane to inhibit spermatozoa-zona pellucida binding. Journal of Cell Science 120 33-44. (doi:10.1242/jcs. 03258)

Chiu PC, Chung MK, Koistinen R, Koistinen H, Seppala M, Ho PC, Ng EH, Lee KF \& Yeung WS 2007b Cumulus oophorus-associated glycodelin-C displaces sperm-bound glycodelin-A and -F and stimulates spermatozoazona pellucida binding. Journal of Biological Chemistry 282 5378-5388. (doi:10.1074/jbc.M607482200)

Clark GF 2011 Molecular models for mouse sperm-oocyte binding. Glycobiology 21 3-5. (doi:10.1093/glycob/cwq159)

Coy P, Canovas S, Mondejar I, Saavedra MD, Romar R, Grullon L, Matas C \& Aviles M 2008 Oviduct-specific glycoprotein and heparin modulate sperm-zona pellucida interaction during fertilization and contribute to the control of polyspermy. PNAS 105 15809-15814. (doi:10.1073/pnas. 0804422105)

Coy P, Lloyd R, Romar R, Satake N, Matas C, Gadea J \& Holt WV 2010 Effects of porcine pre-ovulatory oviductal fluid on boar sperm function. Theriogenology 74 632-642. (doi:10.1016/j.theriogenology.2010. 03.005)

Coy P, García-Vázquez FA, Visconti PE \& Avilés M 2012a Roles of the oviduct in mammalian fertilization. Reproduction $144649-660$. (doi:10.1530/REP-12-0279)
Coy P, Jiménez-Movilla M, García-Vázquez FA, Mondéjar I, Grullón L \& Romar R 2012b Oocytes use the plasminogen-plasmin system to remove supernumerary spermatozoa. Human Reproduction 27 1985-1993. (doi:10.1093/humrep/des146)

Croxatto HB 2002 Physiology of gamete and embryo transport through the Fallopian tube. Reproductive Biomedicine Online 4 160-169. (doi:10.1016/S1472-6483(10)61935-9)

Dalton T, Kover K, Dey SK \& Andrews GK 1994 Analysis of the expression of growth factor, interleukin-1, and lactoferrin genes and the distribution of inflammatory leukocytes in the preimplantation mouse oviduct. Biology of Reproduction 51 597-606. (doi:10.1095/biolreprod51.4.597)

Donnelly KM, Fazleabas AT, Verhage HG, Mavrogianis PA \& Jaffe RC 1991 Cloning of a recombinant complementary DNA to a baboon (Papio anubis) estradiol-dependent oviduct-specific glycoprotein. Molecular Endocrinology 5 356-364. (doi:10.1210/mend-5-3-356)

Dutta B, Ain R, Seshagiri PB \& Karande AA 2001 Differential influence of recombinant non-glycosylated and glycosylated glycodelin on human sperm function: comparative studies with hamster spermatozoa. Reproduction, Fertility, and Development 13 111-118. (doi:10.1071/ RD00119)

Einspanier R, Gabler C, Bieser B, Einspanier A, Berisha B, Kosmann M, Wollenhaupt K \& Schams D 1999 Growth factors and extracellular matrix proteins in interactions of cumulus-oocyte complex, spermatozoa and oviduct. Journal of Reproduction and Fertility Supplement $\mathbf{5 4}$ 359-365.

Ensslin MA, Lyng R, Raymond A, Copland S \& Shur BD 2007 Novel gamete receptors that facilitate sperm adhesion to the egg coat. Journal of Reproduction \& Fertility Supplement 63 367-383.

Gabler C, Chapman DA \& Killian GJ 2003 Expression and localization of osteopontin and integrins in the bovine oviduct during the estrous cycle. Reproduction 126 721-729. (doi:10.1530/rep.0.1260721)

Gad A, Besenfelder U, Rings F, Ghanem N, Salilew-Wondim D, Hossain MM, Tesfaye D, Lonergan P, Becker A, Cinar U et al. 2011 Effect of reproductive tract environment following controlled ovarian hyperstimulation treatment on embryo development and global transcriptome profile of blastocysts: implications for animal breeding and human assisted reproduction. Human Reproduction 26 1693-1707. (doi:10.1093/humrep/der110)

Gahlay G, Gauthier L, Baibakov B, Epifano O \& Dean J 2010 Gamete recognition in mice depends on the cleavage status of an egg's zona pellucida protein. Science 329 216-219. (doi:10.1126/science. 1188178)

Georgiou S, Sostaric E, Wong CH, Snijders APL, Wright PC \& Moore HD 2005 Gametes alter the oviductal secretory proteome. Molecular \& Cellular Proteomics 4 1785-1796. (doi:10.1074/mcp.M500119MCP200)

Georgiou AS, Snijders AP, Sostaric E, Aflatoonian R, Vazquez JL, Vazquez JM, Roca J, Martinez EA, Wright PC \& Fazeli A 2007 Modulation of the oviductal environment by gametes. Journal of Proteome Research 6 4656-4666. (doi:10.1021/pr070349m)

Gervasi MG, Rapanelli M, Ribeiro ML, Farina M, Billi S, Franchi AM \& Perez-Martinez S 2009 The endocannabinoid system in bull sperm and bovine oviductal epithelium: role of anandamide in sperm-oviduct interaction. Reproduction 137 403-414. (doi:10.1530/REP-08-0204)

Gervasi MG, Marczylo TH, Lam PM, Rana S, Franchi AM, Konje JC \& Perez-Martinez S 2013 Anandamide levels fluctuate in the bovine oviduct during the oestrous cycle. PLOS ONE 8 e72521. (doi:10.1371/ journal.pone.0072521)

Gonçalves RF, Wolinetz CD \& Killian GJ 2007 Influence of arginineglycine-aspartic acid (RGD), integrins ( $\alpha \mathrm{V}$ and $\alpha 5)$ and osteopontina on bovine sperm-egg binding, and fertilization in vitro. Theriogenology 67 468-474. (doi:10.1016/j.theriogenology.2006.08.013)

Gonçalves RF, Staros AL \& Killian GJ 2008 Oviductal fluid proteins associated with the bovine zona pellucida and the effect on in vitro sperm-egg binding, fertilization and embryo development. Reproduction in Domestic Animals 43 720-729. (doi:10.1111/j.1439-0531.2007. 00978.x)

Griffiths GS, Miller KA, Galileo DS \& Martin-DeLeon PA 2008 Murine SPAM1 is secreted by the estrous uterus and oviduct in a form that can bind to sperm during capacitation: acquisition enhances hyaluronic acid-binding ability and cumulus dispersal efficiency. Reproduction 135 293-301. (doi:10.1530/REP-07-0340) 
Grippo AA, Way AL \& Killian GJ 1995 Effect of bovine ampullary and isthmic oviductal fluid on motility, acrosome reaction and fertility of bull spermatozoa. Journal of Reproduction \& Fertility 105 57-64. (doi:10.1530/jrf.0.1050057)

Gualtieri R, Boni R, Tosti E, Zagami M \& Talevi R 2005 Intracellular calcium and protein tyrosine phosphorylation during the release of bovine sperm adhering to the fallopian tube epithelium in vitro. Reproduction 129 51-60. (doi:10.1530/rep.1.00374)

Gualtieri R, Mollo V, Barbato V \& Talevi R 2010 Ability of sulfated glycoconjugates and disulfide-reductants to release bovine epididymal sperm bound to the oviductal epithelium in vitro. Theriogenology $\mathbf{7 3}$ 1037-1043. (doi:10.1016/j.theriogenology.2009.11.030)

Hanaue M, Miwa N, Uebi T, Fukuda Y, Katagiri Y \& Takamatsu K 2011 Characterization of S100A11, a suppressive factor of fertilization, in the mouse female reproductive tract. Molecular Reproduction and Development 78 91-103. (doi:10.1002/mrd.21273)

Hao Y, Mathialagan N, Walters E, Mao J, Lai L, Becker D, Li W, Critser J \& Prather RS 2006 Osteopontin reduces polyspermy during in vitro fertilization of porcine oocytes. Biology of Reproduction 75 726-733. (doi:10.1095/biolreprod.106.052589)

Hao Y, Murphy CN, Spate L, Wax D, Zhong Z, Samuel M, Mathialagan N, Schatten H \& Prather RS 2008 Osteopontin improves in vitro development of porcine embryos and decreases apoptosis. Molecular Reproduction and Development 75 291-298. (doi:10.1002/mrd.20794)

Hess AP, Nayak NR \& Giudice LC 2006 Oviduct and endometrium: cyclic changes in the primate oviduct and endometrium. In The Physiology of Reproduction, 3 edn, pp 337-382. Eds E Knobil\& JD Neill. New York, NY: Raven Press.

Hugentobler S, Sreenan J, Humpherson P, Leese H, Diskin M \& Morris D 2010 Effects of changes in the concentration of systemic progesterone on ions, amino acids and energy substrates in cattle oviduct and uterine fluid and blood. Reproduction, Fertility, and Development 22 684-694. (doi:10.1071/RD09129)

Huhtala ML, Seppälä M, Närvänen A, Palomäki P, Julkunen M \& Bohn H 1987 Amino acid sequence homology between human placental protein 14 and beta-lactoglobulins from various species. Endocrinology 120 2620-2622. (doi:10.1210/endo-120-6-2620)

Ignotz GG, Cho MY \& Suarez SS 2007 Annexins are candidate oviductal receptors for bovine sperm surface proteins and thus may serve to hold bovine sperm in the oviductal reservoir. Biology of Reproduction 77 906-913. (doi:10.1095/biolreprod.107.062505)

Ikawa M, Inoue N, Benham AM \& Okabe M 2010 Fertilization: a sperm's journey to and interaction with the oocyte. Journal of Clinical Investigation 120 984-994. (doi:10.1172/JCl41585)

Inoue N, Ikawa M \& Okabe M 2011 The mechanism of sperm-egg interaction and the involvement of IZUMO1 in fusion. Asian Journal of Andrology 13 81-87. (doi:10.1038/aja.2010.70)

Itoh H, Nasu K, Matsumoto H, Kawano Y, Yoshimatsu J \& Narahara H 2006 Hypoxia regulates vascular endothelial growth factor and soluble fmslike tyrosine kinase-1 secretion by human oviductal epithelial cells and stromal fibroblasts. Fertility and Sterility 85 (Suppl 1) 1097-1102. (doi:10.1016/j.fertnstert.2005.10.023)

Izquierdo D, Villamediana P, López-Bejar M \& Paramio MT 2002 Effect of in vitro and in vivo culture on embryo development from prepubertal goat IVM-IVF oocytes. Theriogenology 57 1431-1441. (doi:10.1016/ S0093-691X(02)00647-7)

Kadirvel G, Machado SA, Korneli C, Collins E, Miller P, Bess KN, Aoki K, Tiemeyer M, Bovin N \& Miller DJ 2012 Porcine sperm bind to specific 6-sialylated biantennary glycans to form the oviduct reservoir. Biology of Reproduction 87 147-156. (doi:10.1095/biolreprod.112.103879)

Kan FW \& Esperanzate PW 2006 Surface mapping of binding of oviductin to the plasma membrane of golden hamster spermatozoa during in vitro capacitation and acrosome reaction. Molecular Reproduction and Development 73 756-766. (doi:10.1002/mrd.20459)

Katska L, Kauffold P, Smorag Z, Duschinski U, Torner H \& Kanitz W 1989 Influence of hardening of the zona pellucida on in vitro fertilization of bovine oocytes. Theriogenology 32 767-777. (doi:10.1016/0093-691X (89)90465-2)

Katska L, Kania G, Smorag Z, Wayda E \& Plucienniczak G 1999 Developmental capacity of bovine IVM/IVF oocytes with experimentally induced hardening of the zona pellucida. Reproduction in Domestic Animals 34 255-259. (doi:10.1111/j.1439-0531.1999.tb01248.x)
Kattal N, Cohen J \& Barmat LI 2008 Role of coculture in human in vitro fertilization: a meta-analysis. Fertility and Sterility 90 1069-1076. (doi:10.1016/j.fertnstert.2007.07.1349)

Kavanaugh JF, Grippo AA \& Killian GJ 1992 Cannulation of the bovine ampullary and isthmic oviduct. Journal of Investigative Surgery 5 11-17. (doi:10.3109/08941939209031588)

Kawakami E, Hori T \& Tsutsui T 1998 Induction of dog sperm capacitation by oviductal fluid. Journal of Veterinary Medical Science 60 197-202. (doi:10.1292/jvms.60.197)

Kawakami E, Arai T, Oishi I, Hori T \& Tsutsui T 2000 Induction of dog sperm capacitation by glycosaminoglycans and glycosaminoglycan amounts of oviductal and uterine fluids in bitches. Journal of Veterinary Medical Science 62 65-68. (doi:10.1292/jvms.62.65)

Kawakami E, Kashiwagi C, Hori T \& Tsutsui T 2001 Effects of canine oviduct epithelial cells on movement and capacitation of homologous spermatozoa in vitro. Animal Reproduction Science 68 121-131. (doi:10.1016/ S0378-4320(01)00135-X)

Kawamura K, Kawamura N, Fukuda J, Kumagai J, Hsueh AJ \& Tanaka T 2007 Regulation of preimplantation embryo development by brainderived neurotrophic factor. Developmental Biology 311 147-158. (doi:10.1016/j.ydbio.2007.08.026)

Kervancioglu ME, Saridogan E, Aitken RJ \& Djahanbakhch O 2000 Importance of sperm-to-epithelial cell contact for capacitation of human spermatozoa in fallopian tube epithelial cell cocultures. Fertility and Sterility $\mathbf{7 4}$ 780-784. (doi:10.1016/S0015-0282(00) 01514-4)

Kidson A, Schoevers E, Langendijk P, Verheijden J, Colenbrander B \& Bevers M 2003 The effect of oviductal epithelial cell co-culture during in vitro maturation on sow oocyte morphology, fertilization and embryo development. Theriogenology 59 1889-1903. (doi:10.1016/S0093691X(02)01291-8)

Killian G 2011 Physiology and endocrinology symposium: evidence that oviduct secretions influence sperm function: a retrospective view for livestock. Journal of Animal Science 89 1315-1322. (doi:10.2527/jas. 2010-3349)

Kimura H, Matsuda J, Ogura A, Asano T \& Naiki M 1994 Affinity binding of hamster oviductin to spermatozoa and its influence on in vitro fertilization. Molecular Reproduction and Development 39 322-327. (doi:10.1002/mrd.1080390309)

King RS \& Killian GJ 1994 Purification of bovine estrus-associated protein and localization of binding on sperm. Biology of Reproduction $\mathbf{5 1}$ 34-42. (doi:10.1095/biolreprod51.1.34)

King RS, Anderson SH \& Killian GJ 1994 Effect of bovine oviductal estrusassociated protein on the ability of sperm to capacitate and fertilize oocytes. Journal of Andrology 15 468-478. (doi:10.1002/j.1939-4640)

Kito S \& Bavister BD 1996 Kinetics of sperm penetration and fertilization in vitro in hamster follicular and oviductal ova. Journal of Experimental Zoology 274 373-383. (doi:10.1002/(SICI)1097-010X(19960415)274: 6<373::AID-JEZ6>3.0.CO;2-L)

Kölle S, Dubielzig S, Reese S, Wehrend A, König P \& Kummer W 2009 Ciliary transport, gamete interaction, and effects of the early embryo in the oviduct: ex vivo analyses using a new digital videomicroscopic system in the cow. Biology of Reproduction 81 267-274. (doi:10.1095/ biolreprod.108.073874)

Kouba AJ, Abeydeera LR, Alvarez IM, Day BN \& Buhi WC 2000 Effects of the porcine oviduct-specific glycoprotein on fertilization, polyspermy, and embryonic development in vitro. Biology of Reproduction 63 242-250. (doi:10.1095/biolreprod63.1.242)

Kumaresan A, Johannisson A, Humblot P \& Bergqvist AS 2012 Oviductal fluid modulates the dynamics of tyrosine phosphorylation in cryopreserved boar spermatozoa during capacitation. Molecular Reproduction and Development 79 525-540. (doi:10.1002/mrd.22058)

Lee YL, Lee KF, Xu JS, He QY, Chiu JF, Lee WM, Luk JM \& Yeung WS 2004 The embryotrophic activity of oviductal cell-derived complement $\mathrm{C} 3 \mathrm{~b}$ and $\mathrm{iC} 3 \mathrm{~b}$, a novel function of complement protein in reproduction. Journal of Biological Chemistry 279 12763-12768. (doi:10.1074/jbc. M311160200)

Lee KF, Kwok KL, Chung MK, Lee YL, Chow JF \& Yeung WS 2005 Phospholipid transfer protein (PLTP) mRNA expression is stimulated by developing embryos in the oviduct. Journal of Cellular Biochemistry 95 740-749. (doi:10.1002/jcb.20444) 
Lee KF, Xu JS, Lee YL \& Yeung WS 2006 Demilune cell and parotid protein from murine oviductal epithelium stimulates preimplantation embryo development. Endocrinology 147 79-87. (doi:10.1210/en.2005-0596)

Lee YL, Cheong AW, Chow WN, Lee KF \& Yeung WS 2009 Regulation of complement-3 protein expression in human and mouse oviducts. Molecular Reproduction and Development 76 301-308. (doi:10.1002/ mrd.20955)

Leese HJ 1988 The formation and function of oviduct fluid. Journal of Reproduction \& Fertility 82 843-856. (doi:10.1530/jrf.0.0820843)

Leese $H$, Hugentobler S, Gray S, Morris D, Sturmey R, Whitear S \& Sreenan J 2008 Female reproductive tract fluids: composition, mechanism of formation and potential role in the developmental origins of health and disease. Reproduction, Fertility, and Development 20 1-8. (doi:10.1071/RD07153)

Lin Y, Mahan K, Lathrop WF, Myles DG \& Primakoff P 1994 A hyaluronidase activity of the sperm plasma-membrane protein $\mathrm{Ph}-20$ enables sperm to penetrate the cumulus layer surrounding the egg. Journal of Cell Biology 125 1157-1163. (doi:10.1083/jcb.125.5.1157)

Lippes J, Krasner J, Alfonso LA, Dacalos ED \& Lucero R 1981 Human oviductal fluid proteins. Fertility and Sterility 36 623-629.

Lishko PV, Kirichok Y, Ren D, Navarro B, Chung JJ \& Clapham DE 2012 The control of male fertility by spermatozoan ion channels. Annual Review of Physiology 74 453-475. (doi:10.1146/annurev-physiol020911-153258)

Liu LP, Chan ST, Ho PC \& Yeung WS 1995 Human oviductal cells produce high molecular weight factor(s) that improves the development of mouse embryo. Human Reproduction 10 2781-2786. (doi:10.1093/molehr/1.8.395)

Lyng R \& Shur BD 2009 Mouse oviduct-specific glycoprotein is an eggassociated ZP3-independent sperm-adhesion ligand. Journal of Cell Science 122 3894-3906. (doi:10.1242/jcs.058776)

Maccarrone M, Barboni B, Paradisi A, Bernabò N, Gasperi V, Pistilli MG, Fezza F, Lucidi P \& Mattioli M 2005 Characterization of the endocannabinoid system in boar spermatozoa and implications for sperm capacitation and acrosome reaction. Journal of Cell Science $\mathbf{1 1 8}$ 4393-4404. (doi:10.1242/jcs.02536)

Malette B, Paquette Y, Merlen Y \& Bleau G 1995 Oviductins possess chitinase- and mucin-like domains: a lead in the search for the biological function of these oviduct-specific ZP-associating glycoproteins. Molecular Reproduction and Development 41 384-397. (doi:10.1002/mrd. 1080410315)

Marín-Briggiler C, González-Echeverría MF, Munuce MJ, Ghersevich S, Caille AM, Corrigall V, Panayi G, Hellman U \& Vazquez-Levin MH 2010 Glucose-regulated protein $78(\mathrm{Grp} 78 / \mathrm{BiP})$ is secreted by human oviduct epithelial cells and modulates sperm-zona pellucida binding. Fertility and Sterility 93 1574-1584. (doi:10.1016/j.fertnstert.2008.12.132)

Martus NS, Verhage HG, Mavrogianis PA \& Thibodeaux JK 1998 Enhancement of bovine oocyte fertilization in vitro with a bovine oviductal specific glycoprotein. Journal of Reproduction and Fertility $\mathbf{1 1 3}$ 323-329. (doi:10.1530/jrf.0.1130323)

McCauley TC, Buhi WC, Wu GM, Mao J, Caamano JN, Didion BA \& Day BN 2003 Oviduct-specific glycoprotein modulates sperm-zona binding and improves efficiency of porcine fertilization in vitro. Biology of Reproduction 69 828-834. (doi:10.1095/biolreprod.103. 016444)

Miwa N, Ogawa M, Shinmyo Y, Hiraoka Y, Takamatsu K \& Kawamura S 2010 Dicalcin inhibits fertilization through its binding to a glycoprotein in the egg envelope in Xenopus laevis. Journal of Biological Chemistry 285 15627-15636. (doi:10.1074/jbc.M109.079483)

Monaco E, Gasparrini B, Boccia L, De Rosa A, Attanasio L, Zicarelli L \& Killian G 2009 Effect of osteopontin (OPN) on in vitro embryo development in cattle. Theriogenology 71 450-457. (doi:10.1016/j. theriogenology.2008.08.012)

Mondéjar I, Grullón LA, García-Vázquez FA, Romar R \& Coy P 2012 Fertilization outcome could be regulated by binding of oviductal plasminogen to oocytes and by releasing of plasminogen activators during interplay between gametes. Fertility and Sterility 97 453-461. (doi:10.1016/j.fertnstert.2011.11.032)

Mondéjar I, Avilés M \& Coy P 2013a The human is an exception to the evolutionarily-conserved phenomenon of pre-fertilization zona pellucida resistance to proteolysis induced by oviductal fluid. Human Reproduction 28 718-728. (doi:10.1093/humrep/des423)
Mondéjar I, Martínez-Martínez I, Avilés M \& Coy P 2013b Identification of potential oviductal factors responsible for zona pellucida hardening and monospermy during fertilization in mammals. Biology of Reproduction 89 67-75. (doi:10.1095/biolreprod.113.111385)

Morales P, Palma V, Salgado AM \& Villalón M 1996 Sperm interaction with human oviductal cells in vitro. Human Reproduction 11 1504-1509. (doi:10.1093/oxfordjournals.humrep.a019426)

Mugnier S, Kervella M, Douet C, Canepa S, Pascal G, Deleuze S, Duchamp G, Monget P \& Goudet G 2009 The secretions of oviduct epithelial cells increase the equine in vitro fertilization rate: are osteopontin, atrial natriuretic peptide $\mathrm{A}$ and oviductin involved? Reproductive Biology and Endocrinology 7 129-145. (doi:10.1186/1477-7827-7-129)

Munuce MJ, Serravalle A, Caille A, Zumoffen C, Botti G, Cabada M \& Ghersevich S 2009 Human tubal secretion can modify the affinity of human spermatozoa for the zona pellucida. Fertility and Sterility 91 407-413. (doi:10.1016/j.fertnstert.2007.11.077)

Myles DG \& Primakoff P 1997 Why did the sperm cross the cumulus? To get to the oocyte. Functions of the sperm surface proteins $\mathrm{PH}-20$ and fertilin in arriving at, and fusing with, the egg Biology of Reproduction $\mathbf{5 6}$ 320-327. (doi:10.1095/biolreprod56.2.320)

Nixon B, Asquith KL \& Aitken R 2005 The role of molecular chaperones in mouse sperm-egg interactions. Molecular and Cellular Endocrinology 240 1-10. (doi:10.1016/j.mce.2005.06.004)

O'Day-Bowman MB, Mavrogianis PA, Reuter LM, Johnson DE, Fazleabas AT \& Verhage HG 1996 Association of oviduct-specific glycoproteins with human and baboon (Papio anubis) ovarian oocytes and enhancement of human sperm binding to human hemizonae following in vitro incubation. Biology of Reproduction 54 60-69. (doi:10.1095/biolreprod54.1.60)

Oehninger S, Coddington CC, Hodgen GD \& Seppala M 1995 Factors affecting fertilization: endometrial placental protein 14 reduces the capacity of human spermatozoa to bind to the human zona pellucida. Fertility and Sterility 63 377-383. (doi:10.1016/0020-7292(95)97553-E)

Osycka-Salut C, Gervasi MG, Pereyra E, Cella M, Ribeiro ML, Franchi AM \& Perez-Martinez S 2012 Anandamide induces sperm release from oviductal epithelia through nitric oxide pathway in bovines. PLOS ONE 7 e30671. (doi:10.1371/journal.pone.0030671)

Pauerstein CJ \& Eddy CA 1979 The role of the oviduct in reproduction; our knowledge and our ignorance. Journal of Reproduction and Fertility $\mathbf{5 5}$ 223-229. (doi:10.1530/jrf.0.0550223)

Petrunkina AM, Gehlhaar R, Drommer W, Waberski D \& Töpfer-Petersen E 2001 Selective sperm binding to pig oviductal epithelium in vitro. Reproduction 121 889-896. (doi:10.1530/rep.0.1210889)

Pradeep MA, Jagadeesh J, De AK, Kaushik JK, Malakar D, Kumar S, Dang AK, Das SK \& Mohanty AK 2011 Purification, sequence characterization and effect of goat oviduct-specific glycoprotein on in vitro embryo development. Theriogenology 75 1005-1015. (doi:10. 1016/j.theriogenology.2010.11.007)

Pushpakumara PG, Robinson RS, Demmers KJ, Mann GE, Sinclair KD, Webb R \& Wathes DC 2002 Expression of the insulin-like growth factor (IGF) system in the bovine oviduct at oestrus and during early pregnancy. Reproduction 123 859-868. (doi:10.1530/rep.0.1230859)

Quintero I, Ghersevich S, Caille A, Munuce M, Daniele SM \& Morisoli L 2005 Effects of human oviductal in vitro secretion on spermatozoa and search of sperm-oviductal proteins interactions. International Journal of Andrology 28 137-143. (doi:10.1111/j.1365-2605.2005.00525.x)

Redgrove KA, Anderson AL, McLaughlin EA, O'Bryan MK, Aitken RJ \& Nixon B 2013 Investigation of the mechanisms by which the molecular chaperone HSPA2 regulates the expression of sperm surface receptors involved in human sperm-oocyte recognition. Molecular Human Reproduction 19 120-135. (doi:10.1093/molehr/gas064)

Rodriguez-Martinez H 2007 Role of the oviduct in sperm capacitation. Theriogenology 68 (Suppl 1) S138-S146. (doi:10.1016/j.theriogenology. 2007.03.018)

Roldán-Olarte M, Jiménez-Díaz M \& Miceli DC 2005 Plasminogen detection in oocytes and plasminogen activator activities in the porcine oviduct during the estrous cycle. Zygote 13 115-123. (doi:10.1017/ S0967199405003175)

Romar R, Coy P, Campos I, Gadea J, Matás C \& Ruiz S 2001 Effect of co-culture of porcine sperm and oocytes with porcine oviductal epithelial cells on in vitro fertilization. Animal Reproduction Science 68 85-98. (doi:10.1016/S0378-4320(01)00133-6) 
Rossato M, Ion Popa F, Ferigo M, Clari G \& Foresta C 2005 Human sperm express cannabinoid receptor $\mathrm{Cb} 1$, the activation of which inhibits motility, acrosome reaction, and mitochondrial function. Journal of Clinical Endocrinology and Metabolism 90 984-991. (doi:10.1210/jc. 2004-1287)

Sabeur K, Cherr GN, Yudin AI \& Overstreet JW 1998 Hyaluronic acid enhances induction of the acrosome reaction of human sperm through interaction with the PH-20 protein. Zygote 6 103-111. (doi:10.1017/ S0967199498000021)

Saccary L, She YM, Oko R \& Kan FW 2013 Hamster oviductin regulates tyrosine phosphorylation of sperm proteins during in vitro capacitation. Biology of Reproduction 89 38-49. (doi:10.1095/biolreprod.113. 109314)

Schuel H, Burkman LJ, Lippes J, Crickard K, Forester E, Piomelli D \& Giuffrida A 2002a N-acylethanolamines in human reproductive fluids. Chemistry and Physics of Lipids 121 211-227. (doi:10.1016/S00093084(02)00158-5)

Schuel H, Burkman LJ, Lippes J, Crickard K, Mahony MC, Giuffrida A, Picone RP \& Makriyannis A 2002b Evidence that anandamide-signaling regulates human sperm functions required for fertilization. Molecular Reproduction and Development 63 376-387. (doi:10.1002/mrd.90021)

Sendai Y, Komiya H, Suzuki K, Onuma T, Kikuchi M, Hoshi H \& Araki Y 1995 Molecular cloning and characterization of a mouse oviductspecific glycoprotein. Biology of Reproduction 53 285-294. (doi:10. 1095/biolreprod53.2.285)

Seytanoglu A, Georgiou AS, Sostaric E, Watson PF, Holt WV \& Fazeli A 2008 Oviductal cell proteome alterations during the reproductive cycle in pigs. Journal of Proteome Research 7 2825-2833. (doi:10.1021/ pr8000095)

Shirazi A \& Motaghi E 2013 The in vitro fertilization of ovine oocytes in the presence of oviductal cells and its effect on the expression of zygote arrest 1 (zZar1) and subsequent embryonic development. Journal of reproduction \& infertility $148-16$.

Souza CE, Moura AA, Monaco E \& Killian GJ 2008 Binding patterns of bovine seminal plasma proteins $\mathrm{A} 1 / \mathrm{A} 2,30 \mathrm{kDa}$ and osteopontin on ejaculated sperm before and after incubation with isthmic and ampullary oviductal fluid. Animal Reproduction Science 105 72-89. (doi:10.1016/ j.anireprosci.2007.11.027)

Staros AL \& Killian GJ 1998 In vitro association of six oviductal fluid proteins with the bovine zona pellucida. Journal of Reproduction and Fertility 112 131-137. (doi:10.1530/jrf.0.1120131)

St-Jacques S, Malette B, Chevalier S, Roberts KD \& Bleau G 1992 The zona pellucida binds the mature form of an oviductal glycoprotein (oviductin). Journal of Experimental Zoology 262 97-104. (doi:10.1002/jez. 1402620113)

Suarez SS 2006 Gamete and zygote transport. In The Physiology of Reproduction, 3rd edn, pp 133-148. Eds E Knobil\& JD Neill. New York, NY: Raven Press.

Suarez SS 2008a Regulation of sperm storage and movement in the mammalian oviduct. International Journal of Developmental Biology $\mathbf{5 2}$ 455-462. (doi:10.1387/ijdb.072527ss)

Suarez SS $2008 b$ Control of hyperactivation in sperm. Human Reproduction Update 14 647-657. (doi:10.1093/humupd/dmn029)

Sun XX, Gemzell-Danielsson K, Li HZ, Stâbi B \& Stavreus-Evers A 2006 Expression of heparin-binding epidermal growth factor-like growth factor and its receptors in the human fallopian tube and endometrium after treatment with mifepristone. Fertility and Sterility 85 171-178. (doi:10.1016/j.fertnstert.2005.08.011)

Swangchan-Uthai T, Walsh SW, Alexander SL, Cheng Z, Crowe MA, Evans AC \& Wathes DC 2011 Comparison of mRNA for IGFs and their binding proteins in the oviduct during the peri-oestrous period between dairy heifers and lactating cows. Reproduction 142 457-465. (doi:10.1530/REP-11-0154)

Taitzoglou IA, Kokoli AN \& Killian G) 2007 Modifications of surface carbohydrates on bovine spermatozoa mediated by oviductal fluid: a flow cytometric study using lectins. International Journal of Andrology $\mathbf{3 0}$ 108-114. (doi:10.1111/j.1365-2605.2006.00717.x)

Talevi R, Zagami M, Castaldo M \& Gualtieri R 2007 Redox regulation of sperm surface thiols modulates adhesion to the fallopian tube epithelium. Biology of Reproduction 76 728-735. (doi:10.1095/biolreprod.106.056028)
Talevi R, Barbato V, De lorio S, Mollo V, Capriglione T, Ricchiari L, Samo A \& Gualtieri R 2010 Is there a role for endocannabinoids in sperm-oviduct interaction? Reproduction 140 247-257. (doi:10.1530/REP-10-0095)

Teijeiro JM, Ignotz GG \& Marini PE 2009 Annexin A2 is involved in pig (Sus scrofa) sperm-oviduct interaction. Molecular Reproduction and Development 76 334-341. (doi:10.1002/mrd.20958)

Thomas PG, Ignotz GG, Ball BA, Brinsko SP \& Currie WB 1995a Effect of coculture with stallion spermatozoa on de novo protein synthesis and secretion by equine oviduct epithelial cells. American Journal of Veterinary Research 56 1657-1662.

Thomas PG, Ball BA, Brinsko SP 1995b Changes associated with induced capacitation influence the interaction between equine spermatozoa and oviduct epithelial cells monolayers. In Equine Reproduction VI: Biology of Reproduction Monograph Series I. eds Sharp DC, Bazer FW (Society for the Study of Reproduction, Inc. Madison, Wl:) pp 697-706.

Tienthai P, Kjellén L, Pertoft H, Suzuki K \& Rodriguez-Martinez H 2000 Localization and quantitation of hyaluronan and sulfated glycosaminoglycans in the tissues and intraluminal fluid of the pig oviduct. Reproduction, Fertility, and Development 12 173-182. (doi:10.1071/RD00034)

Tienthai P, Johannisson A \& Rodriguez-Martinez H 2004 Sperm capacitation in the porcine oviduct. Animal Reproduction Science $\mathbf{8 0}$ 131-146. (doi:10.1016/S0378-4320(03)00134-9)

Travis AJ \& Kopf GS 2002 The role of cholesterol efflux in regulating the fertilization potential of mammalian spermatozoa. Journal of Clinical Investigation 110 731-736. (doi:10.1172/JCI0216392)

Tse PK, Lee YL, Chow WN, Luk JM, Lee KF \& Yeung WS 2008 Preimplantation embryos cooperate with oviductal cells to produce embryotrophic inactivated complement-3b. Endocrinology $\mathbf{1 4 9}$ 1268-1276. (doi:10.1210/en.2007-1277)

Tulsiani DR, Chayko CA, Orgebin-Crist MC \& Araki Y 1996 Temporal surge of glycosyltransferase activities in the genital tract of the hamster during the estrous cycle. Biology of Reproduction 54 1032-1037. (doi:10.1095/ biolreprod54.5.1032)

Velasquez LA, Maisey K, Fernandez R, Valdes D, Cardenas H, Imarai M, Delgado J, Aguilera J \& Croxatto HB 2001 PAF receptor and PAF acetylhydrolase expression in the endosalpinx of the human fallopian tube: possible role of embryo-derived PAF in the control of embryo transport to the uterus. Human Reproduction 16 1583-1587. (doi:10. 1093/humrep/16.8.1583)

Verhage HG, Fazleabas AT \& Donnelly K 1988 The in vitro synthesis and release of proteins by the human oviduct. Endocrinology 122 1639-1645. (doi:10.1210/endo-122-4-1639)

Wassarman PM, Chen J, Cohen N, Litscher E, Liu C, Qi H \& Williams Z 1999 Structure and function of the mammalian egg zona pellucida. Journal of Experimental Zoology 285 251-258. (doi:10.1002/(SICl)1097010X(19991015)285:3<251::AID-JEZ8 > 3.0.CO;2-1)

Way AL, Schuler AM \& Killian GJ 1997 Influence of bovine ampullary and isthmic oviductal fluid on sperm-egg binding and fertilization in vitro. Journal of Reproduction and Fertility 109 95-101. (doi:10.1530/jrf.0. 1090095)

Weng Q, Shi Z, Watanabe G \& Taya K 2009 Immunolocalization of NGF and its receptors trkA and p75 in the oviducts of golden hamsters during the estrous cycle. Experimental Animals 58 543-546. (doi:10.1538/expanim.58.543)

Wiemer K, Dale B, Hu Y, Steuerwald N, Maxso WS \& Hoffman DI 1995 Blastocyst development in co-culture: development and morphological aspects. Human Reproduction 10 3226-3232.

Wijayagunawardane MP, Kodithuwakku SP, Yamamoto D \& Miyamoto A 2005 Vascular endothelial growth factor system in the cow oviduct: a possible involvement in the regulation of oviductal motility and embryo transport. Molecular Reproduction and Development 72 511-520. (doi:10.1002/mrd.20379)

Wolf E, Arnold GJ, Bauersachs S, Beier HM, Blum H, Einspanier R, Frohlich T, Herrler A, Hiendleder S, Kolle S et al. 2003 Embryo-maternal communication in bovine - strategies for deciphering a complex crosstalk. Reproduction in Domestic Animals 38 276-289. (doi:10.1046/j. 1439-0531.2003.00435.x)

Wu L \& Sampson NS 2014 Fucose, mannose, and $\beta-N$-acetylglucosamine glycopolymers initiate the mouse sperm acrosome reaction through convergent signaling pathways. ACS Chemical Biology 9 468-475. (doi:10.1021/cb400550j) 
Yao Y, Ho P \& Yeung WS 1999 Effects of human oviductal cell coculture on various functional parameters of human spermatozoa. Fertility and Sterility 71 232-239. (doi:10.1016/S0015-0282(98)00430-0)

Yao Y, Ho P \& Yeung WS 2000 Human oviductal cells produce a factor(s) that maintains the motility of human spermatozoa in vitro. Fertility and Sterility 73 479-486. (doi:10.1016/S0015-0282(99)00563-4)

Yeung WS, Ng VK, Lau EY \& Ho PC 1994 Human oviductal cells and their conditioned medium maintain the motility and hyperactivation of human spermatozoa in vitro. Human Reproduction 9 656-660.

Yeung WS, Lee KF, Koistinen R, Koistinen H, Seppala M, Ho PC \& Chiu PC 2006 Roles of glycodelin in modulating sperm function. Molecular and Cellular Endocrinology 250 149-156. (doi:10.1016/j.mce.2005.12.038)

Yeung WS, Lee KF, Koistinen R, Koistinen H, Seppala M, Ho PC \& Chiu PC 2007 Glycodelin: a molecule with multi-functions on spermatozoa. Society of Reproduction and Fertility Supplement 63 143-151.

Zhang M, Hong H, Zhou B, Jin S, Wang C, Fu M, Wang S \& Xia G 2006 The expression of atrial natriuretic peptide in the oviduct and its functions in pig spermatozoa. Journal of Endocrinology 189 493-507. (doi:10.1677/ joe.1.06483)
Zhu J, Barrat CL, Lippes J, Pacey AA \& Cooke ID 1994 The sequential effects of human cervical mucus, oviductal fluid, and follicular fluid on sperm function. Fertility and Sterility 61 1129-1135.

Zumoffen CM, Caille AM, Munuce MJ, Cabada MO \& Ghersevich SA 2010 Proteins from human oviductal tissue- conditioned medium modulate sperm capacitation. Human Reproduction 25 1504-1512. (doi:10.1093/ humrep/deq063)

Zumoffen CM, Gil R, Caille AM, Morente C, Munuce MJ \& Ghersevich SA 2013 A protein isolated from human oviductal tissue in vitro secretion, identified as human lactoferrin, interacts with spermatozoa and oocytes and modulates gamete interaction. Human Reproduction $\mathbf{2 8}$ 1297-1308. (doi:10.1093/humrep/det016)

Received 12 March 2014

First decision 17 April 2014

Revised manuscript received 26 August 2014

Accepted 4 September 2014 